International Journal of Advanced Academic Research (Sciences, Technology and Engineering) | ISSN: 2488-9849 Vol. 6, Issue 6 (June, 2020) | www.ijaar.org

Journal DOI: 10.46654/ij.24889849

Article DOI: 10.46654/ij.24889849.e6619

\title{
STATE BASED ANALYSIS OF CANDIDATES' WASSCE PARTICIPATION AND ACHIEVEMENT OF FIVE CREDITS PASSES AND ABOVE INCLUDING MATHEMATICS AND ENGLISH LANGUAGE IN NIGERIA
}

\author{
OSUO-SISEKEN UZOMA OGUGUO ${ }^{1}$ AND UCHE VICTOR UBOH ${ }^{1}$ \\ ${ }^{1}$ Department of Mathematics, \\ Federal College of Education (Technical), Omoku, \\ Rivers-State, Nigeria. \\ Correspondence Email: dokufunmi@yahoo.com
}

\begin{abstract}
The level of Candidates' WASSCE participation and achievement of five credit passes including Mathematics and English Language were examined for a period of five years. Validated May/June WAEC results for each State in Nigeria from 2014 to 2018 were collected and analyzed. The result of the study showed that $35.13 \%$ of States had consistent average percentage and above representation of Candidates and $13.51 \%$ of States consistently recorded average percentage of candidates that achieved five credit passes and above including Mathematics and English Language. The result also showed that year 2014 had the highest number of candidates that sat for the examination and the lowest percentage of candidates that achieved five credits and above including Mathematics and English Language. Abia State had the highest mean percentage of $74.11 \%$ and Jigawa State $10.08 \%$ attaining the $1^{\text {st }}$ and $36^{\text {th }}$ positions respectively. It is recommended based on the results of the study that Teachers, Schools and States that have shown consistent high achievement should be applauded, Educational Stakeholders in States with consistent low participation and achievement should identify the causes and profer solution, Federal Ministry of Education, Academic and professional bodies should follow up States with consistent low achievement in order to speedily identify and eliminate the cause, Local Government based studies should be carried out in States with low achievement in order to identify poor performing schools.
\end{abstract}

Keywords: WASSCE participation, WASSCE achievement, Five Credits and above including Mathematics and English Language, States. 


\section{Introduction}

Education in no doubt is the bedrock of human and National development. A Nation's position in today's highly competitive global knowledge economy is directly dependent on the quality of its Human capital- the aggregate of skills and knowledge imparted to its citizens by its education system (Adamu, 2017). A nation's educational attainment most importantly the proportion of the work force with secondary credentials is a significant contributor to the country's ability to compete in the global market place (Skaggs in Jackson, 2015). In Nigeria, the attainment of secondary credential is possible when an individual successfully completes a tertiary (Higher or Post-Secondary) education. Post-Secondary education is highly beneficial to an individual as it creates a path to financial security, economic mobility, personal growth, professional development, leadership opportunities and the promise of a brighter future (Hout in Jackson, 2015). Efficient Human resources are made through the education systems especially Higher Education System by such a nation (Adebisi, 2014).

To be admitted into any of the Higher Education Institutions in Nigeria, one must have successfully undergone a six year Secondary Education Programme and written the Senior Secondary School Certificate Examination (S.S.S.C.E). This examination is organized by examinations bodies such as the West African Examination Council (WAEC), National Examination Council (NECO), National Business and Technical Examination Board (NABTEB). These examination bodies are saddled with providing uniform standard to all examination takers irrespective of the type or method of instruction they have received.

West African Examination Council (WAEC), was set up in 1952 as an inter-territorial body to the five West African countries namely, Nigeria, Ghana, Sierra-Leone, Gambia, Liberia with the major task of reviewing and considering annually the examinations to be held in West Africa and award certificates/Diplomas on the results of examination conducted. WAEC in Nigeria, administers its examination twice annually in May/June for school base and November/December for private candidate. WAEC grading system is as follows, $\mathrm{A}_{1}$ (Excellent), $\mathrm{B}_{2}$ (Very Good), $\mathrm{B}_{3}$ (Good), $\mathrm{C}_{4}$ (Credit), $\mathrm{C}_{5}$ (Credit), $\mathrm{C}_{6}$ (Credit), $\mathrm{D}_{7}$ (Pass), $\mathrm{D}_{8}$ (Pass, $\mathrm{F}_{9}$ (Fail). The choice of WASSCE results was due to its credibility and acceptance by tertiary institutions for Higher learning (Sakiyo and Badau, 2015). The awarding of Senior Secondary School Certificate is one of the most important events in Nigerian academic calendar because of its economic and social importance and the opportunities for higher education for those who possess such certificate (Kpolovie, Olalube \& Ekwebelem, 2011). A basic requirement by most higher education institutions in Nigeria to be admitted is a minimum of five credit pass in subjects relevant to applied course including Mathematics and English Language in West African Secondary School Certificate Examination (WASSCE) organized by WAEC or its equivalent examination body. Utibe \& Agwagah (2015) reported that zones in the country are not performing equally in Mathematics; there are zones with significantly better performance and those with consistently poor performance. They further declared there is urgent need to arrest the poor performances in these zones and to keep up and or improve on the standard of the zones with better performance levels. This is achievable when state by state 
analysis of performance is made since the zones in Nigeria are made up of different States. It is in view of this and the important role of acquisition of higher education that this study is focused on analyzing the pattern of students participation and their obtaining five credit passes and above including Mathematics and English Language from 2014 to 2018 (May/June) years for the 35 States in Nigeria and its Capital (Federal Capital Territory). This State by State analysis which is presented in numerical form will give an explicit view of the level of students participation and achievement of five credit passes and above in the last five years. This will give Policy Makers and Stakeholders in the various State in particular and Nigeria in general a guide on what to do to improve or sustain the level of participation and achievement in WASSCE.

\section{Purpose of the Study}

1. To ascertain the level of participation in May/June WASSCE from 2014 to 2018 years in Nigerian States and Federal Capital Territory (FCT).

2. To ascertain the level of students achievement of five credits and above including Mathematics and English Language in May/June WASSSCE from 2014 to 2018 years in Nigerian States and Federal Capital Territory (FCT)..

3. To ascertain the position of Nigerian States and Federal Capital Territory (FCT) based on students level of obtaining five credit passes including Mathematics and English Language in May/June WASSCE from 2014 to 2018 in Nigeria States and Capital.

\section{Research Questions}

1. What is the level of Students participation in May/June WASSCE from 2014 to 2018 in Nigerian States and FCT.

2. What is the Level of Candidates' achievement of five credit passes and above including Mathematics and English Language in May/June WASSCE from 2014 to 2018 in Nigeria' States and FCT.

3. What is the position of each of Nigerian States and Capital based on candidates' achievement in five credits and above including Mathematics and English Language in May/June WASSSCE from 2014 to 2018.

\section{Method}

The Study adopted the descriptive survey. All the students in the West African Countries of Nigeria, Ghana, Sierra-Leone, Gambia and Liberia who sat for the WASSCE from 2014 to 2018 constitute the population with a sample of 7,886,565 students in Nigeria who sat for the examination were used for the study. The sample was purposively selected. Data was collected from records. The sources of the data are both primary and secondary. 


\section{Data Analysis}

The data collected were analyzed by using frequency count and percentages.

\section{Results}

Research Question One: What is the level of students' participation in May/June WASSCE from 2014 to 2018 in Nigerian States and FCT?

Table 1: Number and Percentage of Candidates that Sat for May/June WASSCE in Nigerian States and FCT from 2014 to 2018 Years.

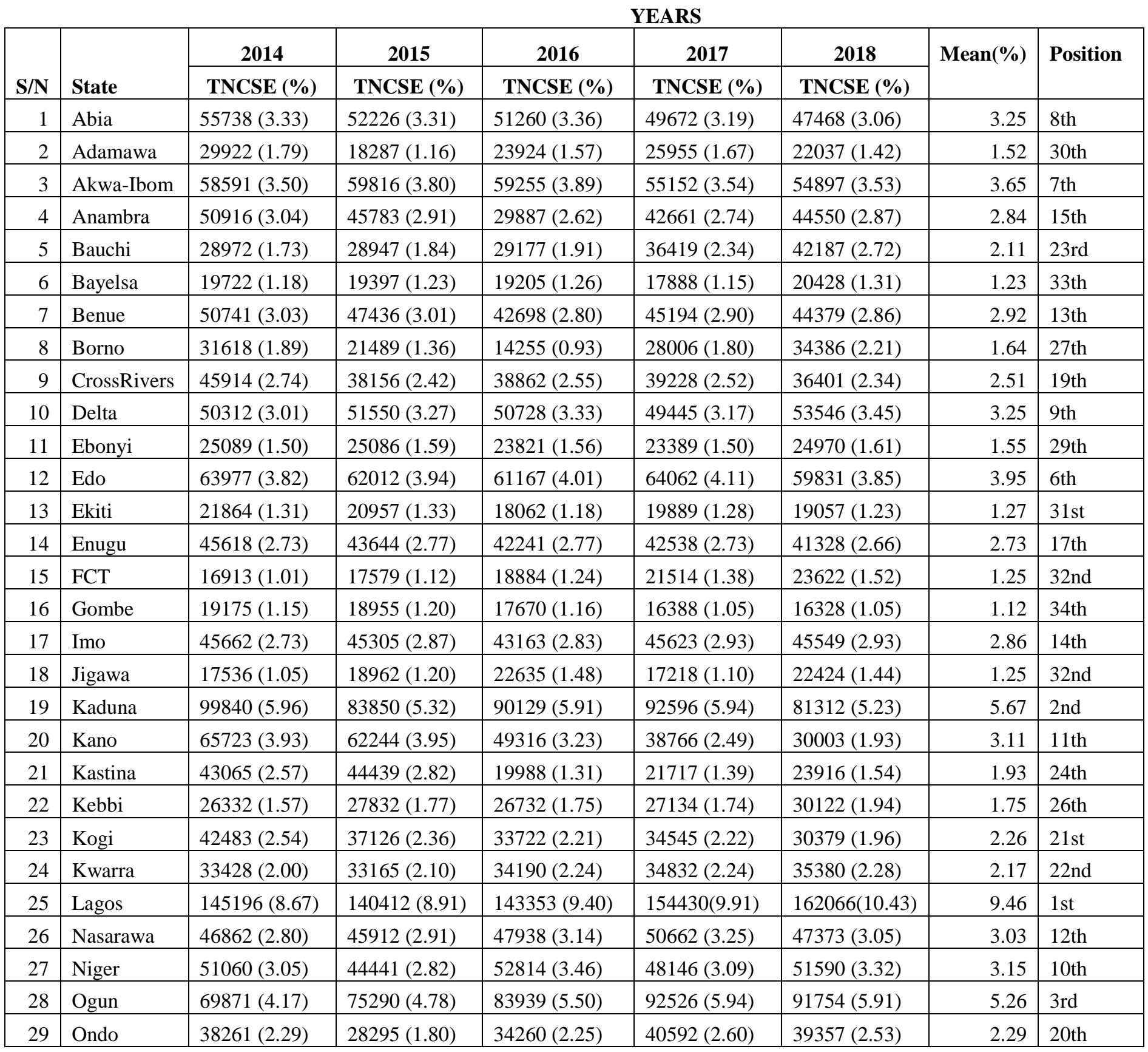


International Journal of Advanced Academic Research (Sciences, Technology and Engineering) | ISSN: $2488-9849$

Journal DOI: 10.46654/ij.24889849

Vol. 6, Issue 6 (June, 2020) | www.ijaar.org

Article DOI: 10.46654/ij.24889849.e6619

\begin{tabular}{|l|l|l|l|l|l|l|l|l|}
\hline 30 & Osun & $47161(2.82)$ & $48299(3.06)$ & $35978(2.36)$ & $32481(2.08)$ & $36171(2.33)$ & 2.53 & 18 th \\
\hline 31 & Oyo & $77321(4.62)$ & $78574(4.99)$ & $70581(4.63)$ & $53850(3.46)$ & $65340(4.21)$ & 4.38 & 4 th \\
\hline 32 & Plateau & $52020(3.11)$ & $42884(2.72)$ & $39922(2.62)$ & $43255(2.78)$ & $39108(2.52)$ & 2.75 & 16 th \\
\hline 33 & Rivers & $63729(3.81)$ & $62610(3.97)$ & $61030(4.00)$ & $61656(3.96)$ & $65005(4.18)$ & 3.98 & 5 th \\
\hline 34 & Sokoto & $24806(1.48)$ & $25475(1.62)$ & $25311(1.66)$ & $27673(1.78)$ & $26084(1.68)$ & 1.64 & 27 th \\
\hline 35 & Taraba & $24066(1.44)$ & $18653(1.18)$ & $18093(1.19)$ & $21754(1.40)$ & N/A & 1.30 & \\
\hline 36 & Yobe & $15143(0.90)$ & $14769(0.94)$ & $13378(0.88)$ & $13297(0.85)$ & $16898(1.09)$ & 0.93 & 35 th \\
\hline 37 & Zamfara & $29120(1.74)$ & $26031(1.65)$ & $27263(1.79)$ & $28196(1.81)$ & $28481(1.83)$ & 1.76 & 25 th \\
\hline & Total & $\mathbf{1 6 7 3 7 6 7}(\mathbf{1 0 0})$ & $\mathbf{1 5 7 5 8 8 8}(\mathbf{1 0 0})$ & $\mathbf{1 5 2 4 8 3 2 ( 1 0 0 )}$ & $\mathbf{1 5 5 8 3 4 9}(\mathbf{1 0 0})$ & $\mathbf{1 5 5 3 7 2 7 ( 1 0 0 )}$ & & \\
\hline
\end{tabular}

Source: Federal Ministry of Education, Nigeria Digest of Education Statistics (2017); National Bureau of Statistics 2019.

Note: TNCSE=Total number of candidate that sat for the examination. N/A = Not available.

Table 1 shows the total number and percentage of candidates that sat for May/June WASSCE from 2014 to 2018 in Nigeria's 36 States and FCT. The result shows that Abia recorded 3.33\%, $3.31 \%, 3.36 \%, 3.19 \%, 3.06 \%$ for years $2014,2015,2016,2017$ and 2018 respectively with a mean percentage of $3.25 \%$. Adamawa recorded $1.79 \%, 1.16 \%, 1.57 \%, 1.67 \%, 1.42 \%$ for years 2014, 2015, 2016, 2017 and 2018 respectively with a mean percentage of 1.52\%. Akwa-Ibom recorded $3.50 \%, 3.80 \%, 3.89 \%, 3.54 \%, 3.53 \%$ for years 2014, 2015, 2016, 2017 and 2018 respectively with a mean percentage of $3.65 \%$. Anambra recorded $3.04 \%, 2.91 \%, 2.62 \%$, $2.74 \%, 2.87 \%$ for years 2014, 2015, 2016, 2017 and 2018 respectively with a mean percentage of $2.84 \%$. Bauchi recorded 1.73\%, 1.84\%, 1.91\%, 2.34\%, 2.72\% for years 2014, 2015, 2016, 2017 and 2018 respectively with a mean percentage of $2.11 \%$. Bayelsa recorded $1.18 \%, 1.23 \%$, $1.26 \%, 1.15 \%, 1.31 \%$ for years 2014, 2015, 2016, 2017 and 2018 respectively with a mean percentage of $1.23 \%$. Benue recorded $3.03 \%, 3.01 \%, 2.80 \%, 2.90 \%, 2.86 \%$ for years 2014 , 2015, 2016, 2017 and 2018 respectively with a mean percentage of $2.92 \%$. Borno recorded $1.89 \%, 1.36 \%, 0.93 \%, 1.80 \%, 2.21 \%$ for years $2014,2015,2016,2017$ and 2018 respectively with a mean percentage of $1.64 \%$. Cross-River recorded $2.74 \%, 2.42 \%, 2.55 \%, 2.52 \%, 2.34 \%$ for years 2014, 2015, 2016, 2017 and 2018 respectively with a mean percentage of $2.51 \%$. Delta recorded $3.01 \%, 3.27 \%, 3.33 \%, 3.17 \%, 3.45 \%$ for years 2014, 2015, 2016, 2017 and 2018 respectively with a mean percentage of $3.25 \%$. Ebonyi recorded $1.50 \%, 1.59 \%, 1.56 \%, 1.50 \%$, $1.61 \%$ for years 2014, 2015, 2016, 2017 and 2018 respectively with a mean percentage of 1.55\%. Edo recorded 3.82\%, 3.94\%, 4.01\%, 4.11\%, 3.85\% for years 2014, 2015, 2016, 2017 and 2018 respectively with a mean percentage of $3.95 \%$. Ekiti recorded $1.31 \%, 1.33 \%, 1.18 \%$, $1.28 \%, 1.23 \%$ for years 2014, 2015, 2016, 2017 and 2018 respectively with a mean percentage of $1.27 \%$. Enugu recorded $2.73 \%, 2.77 \%, 2.77 \%, 2.73 \%, 2.66 \%$ for years $2014,2015,2016$, 2017 and 2018 respectively with a mean percentage of $2.73 \%$. FCT recorded $1.01 \%$, 1.12\%, $1.24 \%, 1.38 \%, 1.52 \%$ for years $2014,2015,2016,2017$ and 2018 respectively with a mean percentage of $1.25 \%$. Gombe recorded $1.15 \%, 1.20 \%, 1.16 \%, 1.05 \%, 1.05 \%$ for years 2014 , 2015, 2016, 2017 and 2018 respectively with a mean percentage of $1.12 \%$. Imo recorded $2.73 \%$, $2.87 \%, 2.83 \%, 2.93 \%, 2.93 \%$ for years $2014,2015,2016,2017$ and 2018 respectively with a 
mean percentage of $2.86 \%$. Jigawa recorded $1.05 \%, 1.20 \%, 1.48 \%, 1.10 \%, 1.44 \%$ for years 2014, 2015, 2016, 2017 and 2018 respectively with a mean percentage of $1.25 \%$. Kaduna recorded 5.96\%, 5.32\%, 5.91\%, 5.94\%, 5.23\% for years 2014, 2015, 2016, 2017 and 2018 respectively with a mean percentage of $5.67 \%$. Kano recorded $3.93 \%, 3.95 \%, 3.23 \%, 2.49 \%$, $1.93 \%$ for years 2014, 2015, 2016, 2017 and 2018 respectively with a mean percentage of $3.11 \%$. Kastina recorded 2.57\%, 2.82\%, 1.31\%, 1.39\%, 1.54\% for years 2014, 2015, 2016, 2017 and 2018 respectively with a mean percentage of $1.93 \%$. Kebbi recorded $1.57 \%, 1.77 \%, 1.75 \%$, $1.74 \%, 1.94 \%$ for years 2014, 2015, 2016, 2017 and 2018 respectively with a mean percentage of 1.75\%. Kogi recorded 2.54\%, 2.36\%, 2.21\%, 2.22\%, 1.96\% for years 2014, 2015, 2016, 2017 and 2018 respectively with a mean percentage of $2.26 \%$. Kwarra recorded $2.00 \%, 2.10 \%$, $2.24 \%, 2.24 \%, 2.28 \%$ for years 2014, 2015, 2016, 2017 and 2018 respectively with a mean percentage of $2.17 \%$. Lagos recorded $8.67 \%, 8.91 \%, 9.40 \%, 9.91 \%, 10.43 \%$ for years 2014 , 2015, 2016, 2017 and 2018 respectively with a mean percentage of $9.46 \%$. Nasarawa recorded $2.80 \%, 2.91 \%, 3.14 \%, 3.25 \%, 3.05 \%$ for years 2014, 2015, 2016, 2017 and 2018 respectively with a mean percentage of $3.03 \%$. Niger recorded $3.05 \%, 2.82 \%, 3.46 \%, 3.09 \%, 3.32 \%$ for years 2014, 2015, 2016, 2017 and 2018 respectively with a mean percentage of $3.15 \%$. Ogun recorded $4.17 \%, 4.78 \%, 5.50 \%, 5.94 \%, 5.91 \%$ for years 2014, 2015, 2016, 2017 and 2018 respectively with a mean percentage of $5.26 \%$. Ondo recorded $2.29 \%, 1.80 \%, 2.25 \%, 2.60 \%$, $2.53 \%$ for years 2014, 2015, 2016, 2017 and 2018 respectively with a mean percentage of $2.29 \%$. Osun recorded $2.82 \%, 3.06 \%, 2.36 \%, 2.08 \%, 2.33 \%$ for years $2014,2015,2016,2017$ and 2018 respectively with a mean percentage of $2.53 \%$. Oyo recorded $4.62 \%, 4.99 \%, 4.63 \%$, $3.46 \%, 4.21 \%$ for years 2014, 2015, 2016, 2017 and 2018 respectively with a mean percentage of $4.38 \%$. Plateau recorded $3.11 \%, 2.72 \%, 2.62 \%, 2.78 \%, 2.52 \%$ for years $2014,2015,2016$, 2017 and 2018 respectively with a mean percentage of $2.75 \%$. Rivers recorded $3.81 \%$, 3.97\%, $4.00 \%, 3.96 \%, 4.18 \%$ for years 2014, 2015, 2016, 2017 and 2018 respectively with a mean percentage of $3.98 \%$. Sokoto recorded $1.48 \%, 1.62 \%, 1.66 \%, 1.78 \%, 1.68 \%$ for years 2014 , 2015, 2016, 2017 and 2018 respectively with a mean percentage of $1.64 \%$. Taraba recorded $1.44 \%, 1.81 \%, 1.19 \%, 1.40 \%$ for years 2014, 2015, 2016, 2017 respectively with a mean percentage of $1.30 \%$ for four years. Yobe recorded $0.90 \%, 0.94 \%, 0.88 \%, 0.85 \%, 1.09 \%$ for years 2014, 2015, 2016, 2017 and 2018 respectively with a mean percentage of $0.93 \%$. Zamfara recorded 1.74\%, 1.65\%, 1.79\%, 1.81\%, 1.83\% for years 2014, 2015, 2016, 2017 and 2018 respectively with a mean percentage of $1.76 \%$.

Research QuestionTwo: What is the level of candidates' achievement of five credit passes and above including Mathematics and English Language in May/June WASSCE from 2014 to 2018 in Nigerian States and FCT? 
International Journal of Advanced Academic Research (Sciences, Technology and Engineering) | ISSN: $2488-9849$

Journal DOI: 10.46654/ij.24889849

Vol. 6, Issue 6 (June, 2020) | www.ijaar.org

Article DOI: 10.46654/ij.24889849.e6619

Table2: Number and percentage of candidates that obtained five credits and above including Mathematics and English Language in Nigeria's 36 States and FCT.

\begin{tabular}{|c|c|c|c|c|c|c|c|c|}
\hline $\mathbf{S} / \mathbf{N}$ & STATE & $\begin{array}{l}2014 \\
\text { FCAME }(\%)\end{array}$ & $\begin{array}{l}2015 \\
\text { FCAME }(\%)\end{array}$ & $\begin{array}{l}2016 \\
\text { FCAME(\%) }\end{array}$ & $\begin{array}{l}2017 \\
\text { FCAME(\%) }\end{array}$ & $\begin{array}{l}2018 \\
\text { FCAME(\%) }\end{array}$ & $\begin{array}{l}\text { MEAN } \\
(\%)\end{array}$ & POSITION \\
\hline 1. & Abia & $33287(59.72)$ & $36548(69.98)$ & $42050(82.03)$ & $38012(76.52)$ & $39056(82.28)$ & 74.11 & $1^{\mathrm{st}}$ \\
\hline 2. & Adamawa & $2094(7.00)$ & $3369(18.42)$ & $10576(44.21)$ & 10913(42.05) & $7611(34.54)$ & 29.24 & $27^{\text {th }}$ \\
\hline 3. & $\begin{array}{l}\text { Akwa- } \\
\text { Ibom }\end{array}$ & $17592(30.03)$ & $23147(38.70)$ & $30143(50.87)$ & $33583(60.89)$ & $29583(53.89)$ & 46.83 & $15^{\text {th }}$ \\
\hline 4. & Anambra & $30867(60.62)$ & $29754(64.99)$ & $28657(71.85)$ & $30515(71.53)$ & $22897(51.40)$ & 64.08 & $5^{\text {th }}$ \\
\hline 5 & Bauchi & $1551(5.35)$ & $4452(15.38)$ & 9805(33.61) & $8511(23.37)$ & $8537(20.24)$ & 19.59 & $32^{\text {nd }}$ \\
\hline 6 & Bayelsa & $10404(52.75)$ & $10448(53.86)$ & $14302(74.47)$ & $14326(80.09)$ & $11895(58.23)$ & 63.88 & $6^{\text {th }}$ \\
\hline 7 & Benue & $12711(25.05)$ & 17662(37.23) & $23391(54.78)$ & $26349(58.30)$ & 20869(47.02) & 44.48 & $17^{\text {th }}$ \\
\hline 8 & Borno & $4472(14.14)$ & $6128(28.52)$ & 7918(55.55) & 12271(43.82) & 7097(20.64) & 32.53 & $26^{\text {th }}$ \\
\hline 9 & $\begin{array}{l}\text { Cross- } \\
\text { Rivers }\end{array}$ & $10098(21.99)$ & $13437(35.22)$ & $23570(60.65)$ & 21521(54.86) & $19573(53.77)$ & 43.30 & $19^{\text {th }}$ \\
\hline 10 & Delta & 19727(39.21) & 24654(47.83) & $32209(63.49)$ & $32071(64.86)$ & 27754(51.83) & 53.44 & $9^{\text {th }}$ \\
\hline 11 & Ebonyi & $8976(35.78)$ & $11463(45.69)$ & $10289(43.19)$ & $15910(68.02)$ & $15500(50.95)$ & 50.95 & $11^{\text {th }}$ \\
\hline 12 & Edo & $36771(57.48)$ & $38929(62.78)$ & $47290(77.31)$ & $48770(76.13)$ & $37334(62.40)$ & 67.22 & $3^{\text {rd }}$ \\
\hline 13 & Ekiti & $7146(32.68)$ & $9211(43.95)$ & $10209(56.52)$ & $14287(71.83)$ & $10827(56.81)$ & 52.36 & $10^{\text {th }}$ \\
\hline 14 & Enugu & $2266(49.67)$ & $20165(46.20)$ & $25703(60.85)$ & $30871(72.57)$ & $25483(61.66)$ & 58.19 & $7^{\text {th }}$ \\
\hline 15 & FCT & 5073(39.99) & 6856(39.00) & $9820(52.00)$ & 13302(61.83) & $12310(52.11)$ & 46.99 & $14^{\text {th }}$ \\
\hline 16 & Gombe & 1091(5.69) & $1431(7.55)$ & $2955(16.72)$ & $4077(24.88)$ & $2747(16.82)$ & 14.33 & $4^{\text {th }}$ \\
\hline 17 & Imo & 17830(39.05) & $24737(54.60)$ & $32876(76.17)$ & $35600(78.03)$ & $34047(74.75)$ & 64.52 & $34^{\text {th }}$ \\
\hline 18 & Jigawa & $1178(6.72)$ & $1308(6.90)$ & $4006(17.70)$ & $1662(9.65)$ & $2113(9.42)$ & 10.08 & $36^{\text {th }}$ \\
\hline 19 & Kaduna & $36001(36.06)$ & $36344(43.34)$ & $51544(57.19)$ & 49298(53.24) & $33116(40.73)$ & 46.11 & $16^{\text {th }}$ \\
\hline 20 & Kano & $16451(25.03)$ & $15966(25.65)$ & 19502(39.54) & $17875(46.11)$ & $16395(54.64)$ & 38.19 & $22^{\text {nd }}$ \\
\hline 21 & Kastina & $4421(10.27)$ & $5566(12.53)$ & $7721(38.63)$ & 11612(53.47) & $7188(30.06)$ & 28.99 & $28^{\text {th }}$ \\
\hline 22 & Kebbi & $1649(6.26)$ & $3513(12.62)$ & $6119(22.89)$ & $11850(43.67)$ & 12167(40.39) & 25.17 & $30^{\text {th }}$ \\
\hline 23 & Kogi & $10150(23.89)$ & $15018(40.45)$ & $16886(50.07)$ & 14885(43.09) & $10270(33.81)$ & 38.26 & $21^{\mathrm{st}}$ \\
\hline 24 & Kwarra & 9659(28.89) & 11926(35.96) & $20320(59.43)$ & $21605(62.03)$ & 17421(49.24) & 47.11 & $13^{\text {th }}$ \\
\hline 25 & Lagos & 67501(46.49) & $71060(50.61)$ & 91784(64.03) & $101150(65.50)$ & $98411(60.72)$ & 57.47 & $8^{\text {th }}$ \\
\hline 26 & Nasarawa & 6416(13.69) & $12302(26.79)$ & $25905(54.04)$ & $27759(54.56)$ & 21131(44.61) & 38.74 & $20^{\text {th }}$ \\
\hline 27 & Niger & $7508(14.70)$ & $9560(21.51)$ & $18327(34.70)$ & 18074(37.54) & $12963(25.13)$ & 26.72 & $29^{\text {th }}$ \\
\hline 28 & Ogun & $18529(26.52)$ & $26518(35.22)$ & $44440(52.94)$ & $50095(54.14)$ & $47432(51.69)$ & 44.10 & $18^{\text {th }}$ \\
\hline 29 & Ondo & $12436(32.50)$ & 11881(41.99) & $23316(68.06)$ & 17970(44.27) & $20550(52.21)$ & 47.81 & $12^{\text {th }}$ \\
\hline 30 & Osun & $8541(18.11)$ & 9114(18.87) & $16469(45.78)$ & $14128(43.50)$ & $14776(40.85)$ & 33.42 & $24^{\text {th }}$ \\
\hline 31 & Oyo & $14754(19.08)$ & 16998(21.63) & $25774(36.52)$ & $28852(53.58)$ & $24742(37.87)$ & 33.74 & $23^{\text {rd }}$ \\
\hline 32 & Plateau & 9138(17.57) & 11541(26.91) & $19776(49.54)$ & 18767(43.39) & 9914(25.35) & 32.55 & $25^{\text {th }}$ \\
\hline 33 & Rivers & $32131(50.42)$ & $37159(59.35)$ & $48053(78.74)$ & $50741(82.30)$ & $50587(77.82)$ & 69.73 & $2^{\text {nd }}$ \\
\hline 34 & Sokoto & $1743(7.03)$ & $4339(17.03)$ & $7425(29.34)$ & $10770(38.92)$ & $8877(34.03)$ & 23.27 & $31^{\mathrm{st}}$ \\
\hline 35 & Taraba & $3354(13.94)$ & $5570(29.86)$ & $11603(64.13)$ & 11195(51.46) & N/A & & \\
\hline 36 & Yobe & $717(4.72)$ & $847(5.73)$ & $1907(14.25)$ & $3550(26.70)$ & $2674(15.82)$ & 13.44 & $35^{\text {th }}$ \\
\hline \multirow[t]{2}{*}{37} & Zamfara & $1927(6.62)$ & 2073(7.96) & $4379(16.06)$ & $8283(29.38)$ & $3404(11.95)$ & 14.38 & $33 \mathrm{rd}$ \\
\hline & Total & $506551(30.02)$ & $590994(38.40)$ & $827019(54.20)$ & $881010(56.53)$ & $747251(48.09)$ & & \\
\hline
\end{tabular}

Source: Federal Ministry of Education, Nigeria Digest of Education Statistics 2017; National Bureau of Statistics.

FCAME=Five credits and above including Mathematics and English Language. N/A = Not Available.

Table 2 shows the Number and percentage of candidates that obtained five credits and above including Mathematics and English Language from 2014 to 2018 for each of the 36 States and FCT. The result showed that Abia recorded 59.72\%, 69.98\%, 82.03\%, 76.53\% and $82.28 \%$ for 
years 2014, 2015, 2016, 2017 and 2018 respectively with mean percentage of 74.11. Adamawa recorded 7.00\%, 18.42\%, 44.21\%, 42.05\% and 34.54\% for years 2014, 2015, 2016, 2017 and 2018 respectively with mean percentage of $29.24 \%$. Akwa-Ibom recorded $30.03 \%$, 38.70\%, $50.87 \%, 60.89 \%$ and $53.89 \%$ for years 2014, 2015, 2016, 2017 and 2018 respectively with mean percentage of 46.88 . Anambra recorded $60.62 \%, 64.99 \%, 71.85 \%, 71.53 \%$ and $51.50 \%$ for years 2014, 2015, 2016, 2017 and 2018 respectively with mean percentage of $64.08 \%$. Bauchi recorded 5.35\%, 15.38\%, 33.613\%, 23.37\% and 20.24\% for years 2014, 2015, 2016, 2017 and 2018 respectively with mean percentage of $19.59 \%$. Bayelsa recorded 52.75\%, $53.86 \%, 74.47 \%, 80.09 \%$ and 58.23\% for years 2014, 2015, 2016, 2017 and 2018 respectively with mean percentage of 63.88 . Benue recorded $25.05 \%, 37.23 \%, 54.78 \%, 58.30 \%$ and $47.02 \%$ for years 2014, 2015, 2016, 2017 and 2018 respectively with mean percentage of $44.48 \%$. Borno recorded $14.14 \%, 28.52 \%, 55.55 \%, 43.82 \%$ and $20.64 \%$ for years $2014,2015,2016$, 2017 and 2018 respectively with mean percentage of $32.53 \%$. Cross-Rivers recorded $21.99 \%$, $35.22 \%, 60.65 \%, 54.86 \%$ and 53.77\% for years 2014, 2015, 2016, 2017 and 2018 respectively with mean percentage of $43.30 \%$. Delta recorded $39.21 \%, 47.83 \%, 63.49 \%, 64.86 \%$ and $51.83 \%$ for years 2014, 2015, 2016, 2017 and 2018 respectively with mean percentage of $53.44 \%$. Ebonyi recorded 35.78\%, 45.69\%, 43.19\%, 68.02\% and 62.07\% for years 2014, 2015, 2016, 2017 and 2018 respectively with mean percentage of $50.95 \%$. Edo recorded $57.48 \%$, $62.78 \%, 77.31 \%, 76.13 \%$ and $62.40 \%$ for years $2014,2015,2016,2017$ and 2018 respectively with mean percentage of $67.22 \%$. Ekiti recorded $32.68 \%, 43.95 \%, 56.52 \%, 71.83 \%$ and $56.81 \%$ for years 2014, 2015, 2016, 2017 and 2018 respectively with mean percentage of $52.36 \%$. Enugu recorded $49.67 \%, 46.20 \%, 60.85 \%, 72.57 \%$ and $61.66 \%$ for years $2014,2015,2016$, 2017 and 2018 respectively with mean percentage of $58.19 \%$. FCT recorded $29.99 \%, 39.00 \%$, $52.00 \%, 61.83 \%$ and $52.11 \%$ for years 2014, 2015, 2016, 2017 and 2018 respectively with mean percentage of $46.99 \%$. Gombe recorded $5.69 \%, 7.55 \%, 16.72 \%, 24.88 \%$ and $16.82 \%$ for years 2014, 2015, 2016, 2017 and 2018 respectively with mean percentage of $14.33 \%$. Imo recorded 39.05\%, 54.60\%, 76.17\%, 78.03\% and 74.75\% for years 2014, 2015, 2016, 2017 and 2018 respectively with mean percentage of $64.52 \%$. Jigawa recorded $6.72 \%, 6.90 \%, 17.70 \%$, $9.65 \%$ and $9.42 \%$ for years 2014, 2015, 2016, 2017 and 2018 respectively with mean percentage of $10.08 \%$. Kaduna recorded $36.06 \%, 43.34 \%, 57.19 \%, 53.24 \%$ and $40.73 \%$ for years 2014, 2015, 2016, 2017 and 2018 respectively with mean percentage of $46.11 \%$. Kano recorded $25.03 \%, 25.65 \%, 39.54 \%, 46.11 \%$ and 54.64\% for years 2014, 2015, 2016, 2017 and 2018 respectively with mean percentage of $38.19 \%$. Kastina recorded $10.27 \%, 12.53 \%, 38.63 \%$, $53.47 \%$ and $30.06 \%$ for years 2014, 2015, 2016, 2017 and 2018 respectively with mean percentage of $28.99 \%$. Kebbi recorded $6.26 \%, 12.62 \%, 22.89 \%, 43.67 \%$ and $40.39 \%$ for years 2014, 2015, 2016, 2017 and 2018 respectively with mean percentage of $25.17 \%$. Kogi recorded $23.89 \%, 40.45 \%, 50.07 \%, 43.09 \%$ and 33.81\% for years 2014, 2015, 2016, 2017 and 2018 respectively with mean percentage of $38.26 \%$. Kwarra recorded $28.89 \%, 35.96 \%, 59.43 \%$, $62.03 \%$ and $49.24 \%$ for years 2014, 2015, 2016, 2017 and 2018 respectively with mean percentage of $47.11 \%$. Lagos recorded $46.49 \%, 50.61 \%, 64.03 \%, 65.50 \%$ and $60.72 \%$ for years 2014, 2015, 2016, 2017 and 2018 respectively with mean percentage of 57.47\%. Nasarawa recorded 13.69\%, 26.79\%, 54.04\%, 54.56\% and 44.61\% for years 2014, 2015, 2016, 2017 and 
2018 respectively with mean percentage of $38.74 \%$. Niger recorded $14.70 \%, 21.51 \%, 34.70 \%$, $37.54 \%$ and $25.13 \%$ for years 2014, 2015, 2016, 2017 and 2018 respectively with mean percentage of $26.72 \%$. Ogun recorded $26.52 \%, 35.22 \%, 52.94 \%, 54.14 \%$ and $51.69 \%$ for years $2014,2015,2016,2017$ and 2018 respectively with mean percentage of $44.10 \%$. Ondo recorded $32.50 \%, 41.99 \%, 68.06 \%, 44.27 \%$ and $52.21 \%$ for years 2014, 2015, 2016, 2017 and 2018 respectively with mean percentage of $47.81 \%$. Osun recorded $18.11 \%, 18.87 \%, 45.78 \%$, $43.50 \%$ and $40.85 \%$ for years 2014, 2015, 2016, 2017 and 2018 respectively with mean percentage of $33.42 \%$. Oyo recorded $19.08 \%, 21.63 \%, 36.52 \%, 53.58 \%$ and $37.87 \%$ for years 2014, 2015, 2016, 2017 and 2018 respectively with mean percentage of $33.74 \%$. Plateau recorded $17.57 \%, 26.91 \%, 49.54 \%, 43.39 \%$ and 25.35\% for years 2014, 2015, 2016, 2017 and 2018 respectively with mean percentage of $32.55 \%$. Rivers recorded $50.42 \%, 59.35 \%, 78.74 \%$, $82.30 \%$ and $77.82 \%$ for years 2014, 2015, 2016, 2017 and 2018 respectively with mean percentage of $69.73 \%$. Sokoto recorded $7.03 \%, 17.03 \%, 29.34 \%, 38.92 \%$ and $34.03 \%$ for years 2014, 2015, 2016, 2017 and 2018 respectively with mean percentage of $23.27 \%$. Yobe recorded $4.72 \%, 5.73 \%, 14.25 \%, 26.70 \%$ and $15.82 \%$ for years 2014, 2015, 2016, 2017 and 2018 respectively with mean percentage of $13.44 \%$. Zamfara recorded $6.62 \%, 7.96 \%, 16.06 \%$, $29.38 \%$ and $11.95 \%$ for years 2014, 2015, 2016, 2017 and 2018 respectively with mean percentage of $14.38 \%$.

Research Question Three: What is the position of each of Nigerian States and Capital based on candidates achievement in five credits and above including Mathematics and English Language in May/June WASSSCE from 2014 to 2018 ?

The positions of States based on candidates achievement of five credits and above including Mathematics and English Language is shown in table 2 as follows: Abia $1^{\text {st }}$ with mean percentage of $74.11 \%$, Rivers $2^{\text {nd }}$ with mean percentage of $69.73 \%$, Edo $3^{\text {rd }}$ with mean percentage of $67.22 \%$, Imo $4^{\text {th }}$ with mean percentage of $64.52 \%$, Anambra $5^{\text {th }}$ with mean percentage of $64.08 \%$, Bayelsa $6^{\text {th }}$ with mean percentage of $63.88 \%$, Enugu $7^{\text {th }}$ with mean percentage of $58.19 \%$, Lagos $8^{\text {th }}$ with mean percentage of $57.47 \%$, Delta $9^{\text {th }}$ with mean percentage of $53.4 \%$, Ekiti $10^{\text {th }}$ with mean percentage of $52.36 \%$, Ebonyi $11^{\text {th }}$ with mean percentage of $50.95 \%$, Ondo $12^{\text {th }}$ with mean percentage of $47.81 \%$, Kwarra $13^{\text {th }}$ with mean percentage of $47.11 \%$, FCT $14^{\text {th }}$ with mean percentage of $46.99 \%$, Akwa-Ibom $15^{\text {th }}$ with mean percentage of $46.83 \%$, Kaduna $16^{\text {th }}$ with mean percentage of $46.11 \%$, Benue $17^{\text {th }}$ with mean percentage of $44.48 \%$, Ogun $18^{\text {th }}$ with mean percentage of $44.10 \%$, Cross-Rivers $19^{\text {th }}$ with mean percentage of $43.30 \%$, Nasarawa $20^{\text {th }}$ with mean percentage of $38.74 \%$, Kogi $21^{\text {st }}$ with mean percentage of $38.26 \%$, Kano $22^{\text {nd }}$ with mean percentage of $38.19 \%$, Oyo $23^{\text {rd }}$ with mean percentage of $33.74 \%$, Osun $24^{\text {th }}$ with mean percentage of $33.42 \%$, Plateau $25^{\text {th }}$ with mean percentage of $32.55 \%$, Borno $26^{\text {th }}$ with mean percentage of $32.53 \%$, Adamawa $27^{\text {th }}$ with mean percentage of $29.24 \%$, Kastina $28^{\text {th }}$ with mean percentage of $28.99 \%$, Niger $29^{\text {th }}$ with mean percentage of $26.72 \%$, Kebbi $30^{\text {th }}$ with mean percentage of $25.17 \%$, Sokoto $31^{\text {st }}$ with mean percentage of $23.27 \%$, Bauchi $32^{\text {nd }}$ with mean percentage of $19.59 \%$, Zamfara $33^{\text {rd }}$ with mean percentage of $14.38 \%$, Gombe $34^{\text {th }}$ with mean percentage of $14.33 \%$, Yobe $35^{\text {th }}$ with mean percentage of $13.44 \%$, Jigawa $36^{\text {th }}$ with mean percentage of $10.08 \%$. 


\section{Discussion of findings}

The result of the study showed that Abia, Akwa-Ibom, Benue, Delta, Edo, Imo, Kaduna, Lagos, Nasarawa, Niger, Ogun, Oyo, Rivers consistently had high percentage (average percentage and above) representation of the candidates that sat for the May/June WASSCE from 2014-2018 years with Lagos having the highest percentage for the five years studied while Adamawa, Bayelsa, Borno, Ebonyi, Ekiti, FCT, Gombe, Jigawa, Kebbi, Kogi, Kwarra, Ondo, Sokoto, Yobe,Zamfara consistently had low percentage (below average percentage) representation of candidates with Yobe and Gombe having the lowest for Four consecutive years and one year respectively. Similarly, Abia, Anambra, Bayelsa, Edo, Rivers consistently recorded high percentage (average percentage and above) of candidates that achieved five credits and above including Mathematics and English Language with Rivers having the highest percentage of 82.30\% while Adamawa, Bauchi, Gombe, Jigawa, Kebbi, Niger, Osun, Plateau, Sokoto, Yobe, Zamfara consistently recorded low percentage (below average percentage) of candidates that achieved five credits and above including Mathematics and English Language with Yobe having the least percentage of $4.72 \%$ in year 2014. Bayelsa, Rivers and Edo which are among the five States that consistently had high percentage of candidates that achieved five credits and above including Mathematics and English Language are States from the South-South zone while Adamawa, Bauchi, Gombe,Yobe States from the North East are among the States that consistently recorded low percentage. This aligns with the findings of Utibe and Agwagah (2015) that South-South Zone performs best with the highest percentage performance while North-East has the least. Also, the findings of the study revealed that years 2014 recorded the highest number of candidates that sat for WASSCE and the lowest number/percentage of candidates that achieved five credits and above including Mathematics and English Language. This shows that most of the states that recorded consistent high percentage of candidates that sat for the WASSCE had no consistency in achieving five credits and above including Mathematics and English Language. This finding is in consonance with the study of Sakiyo and Badau (2015) who reported the existence of a steady increase in the enrolment of students who sat for the May/June WASSCE in Biology, Chemistry, Physics, Mathematics and English from 20082012 in Nigeria without a steady increase in the students' academic achievement. The result also showed that very few States $(29.73 \%$ ) had high mean percentage with Abia having the highest mean percentage of $74.11 \%$ obtaining the $1^{\text {st }}$ position and Jigawa the lowest mean percentage of $10.08 \%$ obtaining the $36^{\text {th }}$ position.

\section{Conclusion}

The State by State study has revealed that few States had high percentage level of candidates' participation in May/June WASSCE. Similarly, very few States had average and above percentage of candidates that obtained five credits and above including Mathematics and English Language. Although, most of the States recorded a significant percentage increase of candidates who obtained five credits and above including Mathematics and English Language in 2016, 2017 and 2018, only 11 States obtained a high mean percentage above average. This will 
certainly strain and retard human and resource development in the States in particular and Nigeria in general.

\section{Recommendation}

The following recommendations are made based on the findings of the study:

1. The Federal Ministry of Education, WAEC, academic and professional bodies should applaud teachers, schools, states that have shown consistent high participation and achievements in order to encourage them to sustain and improve on their existing performances.

2. Educational stakeholders in States with consistent low participation and achievements should identify its cause and profer solution.

3. Federal Ministry of Education, academic and professional bodies should follow up States with consistent low achievement in order to speedily identify and eliminate the cause.

4. Qualified teachers, conducive learning environment, maintenance of infrastructure should be ensured in all secondary schools.

5. Study should be carried out in Local Government Areas of States with consistent low achievement to identify poor performing schools. 


\section{References}

Adamu, A. (2017). Federal Nigerian, Digest of Education Statistics (2014-2016).

Adebisi, T.A. (2014). Higher Education and Skills Development: An Overview of Nigerian National Policy on Education (NPE). International Journal of Development and Sustainability. 3(12), 2218-2227.

Federal ministry of Education, Digest of Education Statistics, August 2017.

Jackson, L. (2015). Higher Education Plays Critical Role in Society: More Women Leaders can make a Difference. Forum on Public Policy.Retrieved on $10^{\text {th }}$ April, 2020 from https://files.eric.ed.gov/fulltext/EJ1091521.pdf.

Kpolovie, P.J; Ololube, N.P \& Ekwebelem, A.B.I. (2011).Appraising the Performance of Secondary School Students on the WAEC \& NECO SSCE from 2004 to 2006.International Journal of Scientific Research in Education. 4(2), 105-114.

National Bureau of Statistics (WAEC Results Statistics) September, 2019.

Sakiyo, S.J. \& Badau, K.M. (2015). Assessment of the Trend of Secondary School Students' Academic Performance in the Sciences, Mathematics and English: Implication for the attainment of the Millenium Development Goals in Nigeria. Advances in Social Sciences Research Journal. 2(2), 31-38.

Utibe, U.J. \& Agwagah, U.N. (2015).A Decade of Candidates' Performance in NECO-SSCE Mathematics in Nigeria. Journal of Education and Practice. 6(25), 25-29. 